\title{
DASAR HUKUM DAN KEDUDUKAN SERTA TUGAS MAUPUN WEWENANG KOMISI KEJAKSAAN DALAM BINGKAI SISTEM KETATANEGARAAN INDONESIA SEBAGAI NEGARA HUKUM
}

\author{
Hotma P. Sibuea ${ }^{1}$, Elfirda Ade Putri ${ }^{2}$ \\ ${ }^{12}$ Fakultas Hukum, Universitas Bhayangkara Jakarta Raya \\ Email: pardomuansibuea58@gmail.com, elfirdade.putri@gmail.com
}

Diterima : 07 Sep 2020 | Direvisi : 02 Okt 2020| Disetujui : 23 Okt 2020| Diterbitkan : 14 Des 2020

\begin{abstract}
The Prosecutor's Commission is a supporting state organ established by virtue of Presidential Decree No. 18/2011 to oversee the implementation of the duties and performance of prosecutors and public prosecutors. However, in practice, the Prosecutorial Commission experiences obstacles and constraints stemming from the regulations governing the Prosecutorial Commission. Research problems that can be determined are as follows. First, can the legal basis, position, duties and powers of the Prosecutor's Commission based on Presidential Regulation Number 18 of 2011 be able to encourage the improvement of the quality of performance of prosecutors and staff of the Attorney General's Office, as desired in Article 38 of Law Number 16 of 2004 concerning the Prosecution? Second, do you need to change the legal basis, position, duties and powers of the Prosecutor's Commission in order to boost the quality of the prosecutor's performance in accordance with the mandate of Article 38 of Law Number 16 Year 2004? The research method used is the juridical-normative research method. There are 2 (two) conclusions put forward, namely as follows. First, the legal basis, position, duties and powers of the Prosecutor's Commission based on Presidential Regulation Number 18 of 2011 cannot encourage the improvement of the performance of prosecutors and public prosecutors as required by Article 38 of Law Number 16 of 2004 concerning the Public Prosecution Service. Second, the legal basis, position, duties and powers of the Prosecutor's Commission need to be changed so that the supporting state organs can encourage the improvement of the performance quality of the Attorney General's Office in accordance with the mandate of Article 38 of Law Number 16 Year 2004. In relation to the two conclusions, suggestions that can be put forward are as follows. First, Presidential Decree Number 18 Year 2011 must be amended immediately with regard to the legal basis, position, duties and powers of the Prosecutor's Commission and articles that obstruct the implementation of the Prosecutor's Commission's duties and powers. Second, the legal basis for the Prosecutorial Commission needs to be upgraded to become a law and its position as an autonomous (independent) supporting state organ accompanied by an authority that determines the results of the implementation of its duties as an external supervisory agency.
\end{abstract}

Keywords: The Prosecutor's Commission, supporting state organs, the prosecutor's external supervisory agency

Komisi Kejaksaan adalah organ negara penunjang yang dibentuk berdasarkan Perpres Nomor 18 Tahun 2011 untuk mengawasi pelaksanaan tugas dan kinerja jaksa dan pegawai kejaksaan. 
Namun, dalam praktik, Komisi Kejaksaan mengalami hambatan dan kendala yang bersumber justru dari regulasi yang mengatur Komisi Kejaksaan.Masalah penelitian yang dapat ditetapkan adalah sebagai berikut. Pertama, apakah dasar hukum, kedudukan, tugas dan wewenang Komisi Kejaksaan berdasarkan Peraturan Presiden Nomor 18 Tahun 2011 dapat mendorong peningkatan kualitas kinerja jaksa dan pegawai Kejaksaan seperti dikehendaki Pasal 38 Undang-undang Nomor 16 Tahun 2004 tentang Kejaksaan? Kedua, apakah dasar hukum, kedudukan, tugas dan wewenang Komisi Kejaksaan perlu diubah supaya dapat mendorong kualitas kinerja Kejaksaan sesuai dengan amanat Pasal 38 UU Nomor 16 Tahun 2004? Metode penelitian yang dipergunakan adalah metode penelitian yuridis-normatif. Ada 2 (dua) simpulan yang dikemukakan yakni sebagai berikut. Pertama, dasar hukum, kedudukan, tugas dan wewenang Komisi Kejaksaan berdasarkan Peraturan Presiden Nomor 18 Tahun 2011 tidak dapat mendorong peningkatan kinerja jaksa dan pegawai Kejaksaan seperti dikehendaki Pasal 38 UU Nomor 16 Tahun 2004 tentang Kejaksaan. Kedua, dasar hukum, kedudukan, tugas dan wewenang Komisi Kejaksaan perlu diubah supaya organ negara penunjang tersebut dapat mendorong peningkatan kualitas kinerja Kejaksaan sesuai dengan amanat Pasal 38 UU Nomor 16 Tahun 2004. Dalam hubungan dengan kedua simpulan tersebut, saran-saran yang dapat dikemukakan adalah sebagai berikut. Pertama, Penpres Nomor 18 Tahun 2011 harus segera diamandemen berkenaan dengan dasar hukum, kedudukan, tugas dan wewenang Komisi Kejaksaan dan pasal yang menghambat pelaksanaan tugas dan wewenang Komisi Kejaksaan. Kedua, dasar hukum Komisi Kejaksaan perlu ditingkatkan menjadi undang-undang dan kedudukannya menjadi organ negara penunjang otonom (mandiri) yang disertai dengan wewenang yang bersifat menentukan hasil pelaksanaan tugasnya sebagai lembaga pengawas eksternal.

Kata kunci : Komisi Kejaksaan, organ negara penunjang, lembaga pengawas eksternal kejaksaan

\section{PENDAHULUAN}

Negara Indonesia adalah negara hukum demokratis berdasarkan Pancasila. Pasal 1 ayat 3 (tiga) Undang-undang Dasar 1945 menyebutkan "Negara Indonesia adalah Negara Hukum." Asas negara hukum adalah salah satu asas hukum tertinggi dalam hierarkhi asas-asas hukum Indonesia. Asas negara hukum sederajat dengan asas demokrasi dalam Pasal 1 ayat (2) UUD 1945 yang menyebutkan "Kedaulatan berada di tangan rakyat dan dilaksanakan menurut Undang-undang Dasar." Asas negara hukum dan asas demokrasi berkonvergensi melahirkan suatu kombinasi asas hukum baru yakni asas negara hukum demokratis atau asas demokrasi yang berdasarkan hukum. ${ }^{1}$ Asas negara hukum demokratis Indonesia berbeda dari asas negara hukum demokratisEropa meskipun memiliki persamaan. Asas negara hukum yang berkembang muila-mula di benua Eropa adalah genus negara hukum. Genus negara hukum berkembang di berbagai negara sesuai dengan konteks lingkungan, sejarah, nilai-nilai budaya, falsafah dan lain-lain sehingga menghasilkan spesies negara hukum. Asas negara hukum demokratis Indonesia adalah spesies negara hukum demokratis yang berpedoman pada falsafah negara, alam lingkungan, sejarah dan budayaIndonesia yang berbeda dari landasan falsafah negara hukum demokratis Eropa. ${ }^{2}$ Asas negara hukum demokratis Indonesia berpedoman pada falsafah negara Pancasila sehingga negara hukum Indonesia dapat disebut negara hukum Pancasila.

\footnotetext{
${ }^{1}$ Hendra Nurtjahya, Filsafat Demokrasi (Jakarta, Bumi Aksara, 2006), hlm.44.

${ }^{2}$ Padmo Wahyono, Indonesia Ialah Negara Yang Berdasarkan Atas Hukum (Jakarta, Ghalia Indonesia, 1983), hlm. 1.
} 
Pancasila adalah sumber nilai-nilai kehidupan bernegara dan praktik penyelenggaraan negara di Indonesia.

Secara lazim, asas negara hukum memiliki beberapa elemen (unsur) utama yakni asas legalitas, asas perlindungan hak-hak asasi manusia, asas peradilan administrasi negara yang otonom dan pemisahan kekuasaan. ${ }^{3}$ Elemen (unsur) pemisahan kekuasaan adalah titik fokus perbincangan. Elemen (unsur) pemisahan kekuasaan adalah sendi (asas/prinsip) hukum penataan kekuasaan organ-organ negara. Elemen pemisahan kekuasaan dipakai sebagai asas distribusi kekuasaan. ${ }^{4}$ Pemisahan kekuasaan bertujuan untuk mencegah konsentrasi kekuasaan pada salah satu organ negara. Upaya pencegahan konsentrasi kekuasaan tersebut dilakukan untuk mencegah penyalahgunaan wewenang atau tindakan sewenang-wenang. Kedua jenis tindakan tersebut berpotensi melanggar hak-hak warga negara dan hak-hak asasi manusia.Namun, pemisahan kekuasaan yang bersifat mutlak dapat melahirkan kekuasaan yang sewenang-wenang yang mengakibatkan penyalahgunaan kekuasaan dan tindakan sewenang-wenangjika tanpa pengawasan. Pengawasan yang diterapkan dalam konteks pemisahan kekuasaan adalah mekanisme check and balances.

Dalam sistem ketatanegaraan Indonesia, mekanisme check and balances diterapkan secara luas dalam lingkungan kekuasaan legislatif, eksekutif dan yudisial. ${ }^{5}$ Dalam lingkungan kekuasaan legislatif,mekanisme check and balancesditerapkan dalam wujud distribusi kekuasaan di antara MPR, DPR dan DPD dengan ruang lingkup wewenang dan tugas yang berbeda. Dalam lingkungan kekuasaan yudisial, mekanisme checks and balancesditerapkan dengan distribusi wewenang dan tugas yang berbeda kepada Mahkamah Agung dan Mahkamah Konstitusi. Bahkan, dalam konteks check and balances, Mahkamah Yudisial dibentuk sebagai lembaga pengawasperilaku hakim-hakim. Mekanisme check and balancejuga diterapkan dalam relasi kekuasaan eksekutif dengan legislatif dalam bentuk mekanisme impeachmentDPR terhadap Presiden/Wakil Presiden. Bahkan, mekanisme check and balance diterapkan dalam lingkungan organ-organ negara yang tidak termasuk organ negara utama. Mekanisme check and balances diterapkan di organorgan antara penunjang Komisi Kepolisian dengan Kepolisian Republik Indonesiadan Komisi Kejaksaan dengan Kejaksaan dalam lingkungan kekuasaan eksekutif. Secara khusus, penelitian bertujuan meneliti mekanisme check and balancedi antara Komisi Kejaksaan dengan Kejaksaan yang termasuk lingkungan kekuasaan eksekutif.

Pembentukan Komisi Kejaksaan dilakukan sesuai dengan amanat Pasal 38 Undang-undang Nomor 16 Tahun 2004 tentang Kejaksaan sebagai berikut "Untuk meningkatkan kualitas kinerja Kejaksaan, Presiden dapat membentuk sebuah komisi yang susunan dan kewenangannya diatur oleh Presiden."Amanat UU Nomor 16 Tahun 2004 mengindikasikan kinerja lembaga pengawas internal Kejaksaan tidak berfungsi maksimal. Sebagai konsekuensinya, Kejaksaan perlu diawasi lembaga pengawas eksternal yang diharapkanbebasdari faktor kepentingan korps dan institusi. Amanat Pasal 38 UU Nomor 16 Tahun 2004 dilaksanakan Presiden dengan membentuk Komisi Kejaksaan berdasarkan Peraturan Presiden Nomor 18 Tahun 2004.

Komisi Kejaksaan bertugas dan berwenang melakukan pengawasan kinerja jaksa dan pegawai kejaksaan menurut Pasal 10 dan Pasal 11 Peraturan Presiden Nomor 18 Tahun 2004.Namun, pada awal berkiprah, kegamangan masih menyertai

\footnotetext{
${ }^{3}$ Hotma Pardomuan Sibuea, Dinamika Negara Hukum (Depok, Rajawali Pers, 2020), hlm. 236.

${ }^{4}$ Jimly Asshiddiqie, Format Kelembagaan negara dan Pergeseran Kekuasaan Dalam UUD 1945 (Yogjakarta, UII-Press,2004), hlm. 11.

5 Jimly Asshiddiqie, Konstitusi dan Konstitusionalisme Indonesia (Jakarta, Mahkamah Konstitusi bekerjasama dengan Pusat Kajian Hukum Tata Negara Universitas Indonesia, 2004), hlm. 58.
} 
pelaksanaan tugas dan wewenang Komisi Kejaksaan. Sesuai dengan tugas dan wewenangnya, kinerja Komisi Kejaksaandianggap tidak maksimal karena berbagai macam faktor. Wewenang dan tugas Komisi Kejaksaan seperti diatur Perpres Nomor 18 Tahun 2005 tidak menunjang kinerja Komisi Kejaksaan seperti dikehendaki UU Nomor 16 Tahun 2004. Dalam konteks pelaksanaan tugas dan wewenang, Komisi Kejaksaanyang bertugas melakukan pengawasan untuk peningkatan kualitas kinerja Kejaksaan dianggap tidak mencapai harapan Pasal 38 UU Nomor 16 Tahun 2004.Sebagai konsekuensinya, beberapa aspek lembaga Komisi Kejaksaan dianggap perlu diubah antara lain berkenaan dengan (1) penambahan wewenang, (2) anggota, (3) kesekretariatan dan (4) pembiayaan. ${ }^{6}$

Sebagai konsekuensinya, Presiden mencabut Peraturan Presiden Nomor 18 Tahun 2005. Sebagai penggantinya, Presiden menetapkan Peraturan Presiden Nomor 18 Tahun 2011 dengan maksud untuk meningkatkan kinerja Komisi Kejaksaan. Beberapa aspek tugas dan wewenang Komisi Kejaksaan mengalami perubahandan diharapkan mendorong peningkatan kinerja Komisi Kejaksaan.Perubahan tugas dan wewenang tersebut menjadi dasar bagi Komisi Kejaksaaan untuk melakukan kiprah yang lebih baik dan berkualitas. Namun, sampai dengan sekarang, sebagai lembaga pengawas eksternal, Komisi Kejaksaan belum menunjukkan kinerja yang dapat meningkatkan kualitas kinerja jaksa dan pegawai kejaksaan. Kondisi tersebut tercermin dari berbagai kasus yang melibatkan oknum jaksa seperti kasus Djoko Tjandra yang melibatkan Jaksa Pinangki Sirna Malasari yang menjadi perbincangan masyarakat.

Kinerja Komisi Kejaksaan yang belum maksimal terjadi karena berbagai macam faktor hambatan dan kendala internal maupun eksternal. Dalam konteks kinerja pengawasan Komisi Kejaksaan yang belum optimal, Sulis Setyowati mengemukakan komentar sebagai berikut "Namun komisi yang dibentuk pertama kali untuk menjadi mitra bagi Kejaksaan untuk meningkatkan kinerjanya itu tidak dapat berbuat banyak. Bahkan, beberapa peristiwa yang terkait dengan dugaan suap yang diterima oleh pejabat Kejaksaan seakan menjadi bukti bahwa komisi ini sebenarnya tidak memiliki kewenangan yang cukup kuat."7 Kinerja Komisi Kejaksaan yang belum maksimal karena belum mampu mendorong peningkatan kualitas kinerja jaksa dan pegawai kejaksaan adalah alasan yang memotivasi para penulis melakukan penelitian hukum dengan topik Komisi Kejaksaan.

Sesuai dengan latar belakang penelitian yang dipaparkan di atas, para penulis dapat merumuskan beberapa masalah penelitia. Masalah penelitian yang dapat dirumuskan adalah sebagai berikut:

1. Apakah dasar hukum, kedudukan, tugas dan wewenang Komisi Kejaksaan berdasarkan Peraturan Presiden Nomor 18 Tahun 2011 dapat mendorong peningkatan kualitas kinerja jaksa dan pegawai Kejaksaan seperti dikehendaki Pasal 38 Undang-undang Nomor 16 Tahun 2004 tentang Kejaksaan?

\footnotetext{
${ }^{6}$ Nur Syarifah, Meninjau Efektivitas Kewenangan Komisi Kejaksaan (Media Hukum dan Keadilan teropong, Volume 1 November 2013), hlm. 19.

7 Sulis Setyowaty dan Guntarto Widodo, Efektivitas Rekomendasi Komisi Kejaksaan Republik Indonesia Dalam Penanganan Laporan Pengaduan Masyarakat (Prosiding Seminar Nasional Enchancing Inovations for Sustainable Development: Dissemination of Unpam's Research Result, Openjournal.unpam.ac.id. Tangerang, 2020), hlm. 2.
} 
2. Apakah dasar hukum, kedudukan, tugas dan wewenang Komisi Kejaksaan perlu diubah supaya Komisi Kejaksaan dapat melakukan upaya peningkatan kualitas kinerja Kejaksaan?

\section{METODE PENELITIAN}

Metode penelitian yang dipergunakan dalam penelitian ini adalah metode penelitian yuridis-normatif yakni metode penelitian yang meneliti norma-norma hukum positif dengan asas-asas hukum dan doktrin-doktrin hukumnya. Metode penelitian yuridis-normatif adalah metode penelitian yang meneliti bahan-bahan hukum yang sudah didokumentasikan. Bahan-bahan hukum tersebut terdiri atas (1) bahan hukum primer, (2) bahan hukum sekunder dan (3) bahan hukum tersier. Dalam konteks penelitian yuridis-normatif untuk meneliti bahan-bahan hukum yang disebutkan di atas, penulis mempergunakan metode penafsiran yakni penafsiran gramatika, penafsiran historis, penafsiran teleologis.

\section{PEMBAHASAN}

\section{Pelaksanaan Tugas dan Wewenang Komisi Kejaksaan Sebagai Mitra Kejaksaan Berdasarkan Peraturan Presiden Nomor 18 Tahun 2011}

Pada tahun 1999-2002, bangsa Indonesia melakukan reformasi konstitusi secara formal untuk pertama kali. Reformasi konstitusi tersebut dilakukan dengan tujuan menata ulang distribusi kekuasaan organ-organ negara.Amandemen konstitusi tersebut membawa perubahan drastis terhadap sistem ketatanegaraan terutama sistem kelembagaan negara. ${ }^{8}$ Amandemen UUD 1945 bertujuan membangun sistem ketatanegaraan dan sistem pemerintahan yang demokratis. ${ }^{9}$ Sistem ketatanegaraan dan pemerintahan yang demokratis dibangun berdasarkan prinsip checks and balance. ${ }^{10}$ Distribusi kekuasaan perlu ditata ulang karena UUD 1945 memberikan kekuasaan yang terlampau besar kepada Presiden. Kekuasaan Presiden yang terlampau besar melahirkan rezim pemerintahan otoriter. ${ }^{11}$

Penataan kembali distribusi kekuasaan yang meliputi kekuasaan legislatif, eksekutif dan judisialdiharapkan dapat membangun mekanisme check and balance di antara organ-organ negara. Dalam lingkungan kekuasaan eksekutif, kekuasaan Presiden sebagai kepala pemerintahan dan kepala negara dipertegas dalam bingkai checks and balances dengan DPR. Dalam lingkungan kekuasaan legislatif, kekuasaan didistribusikan kepada MPR, DPR dan DPD dengan ruang lingkup wewenang masingmasing yang berbeda. Distribusi ulang kekuasaan legislatif bertujuan membangun mekanisme checks and balancesdi antara organ-organ kekuasaan legislatif.

\footnotetext{
${ }^{8}$ Jimly Asshiddiqie mengemukakan komentar sebagai berikut "Dalam empat kali perubahan itu, materi UUD 1945 yang asli telah mengalami perubahan besar-besaran dan dengan perubahan materi yang dapat dikatakan sangat mendasar. Secara substantif, perubahan yang telah terjadi atas UUD 1945 telah menjadikan konstitusi proklamasi itu menjadi konstitusi yang baru sama sekali, meskipun tetap dinamakan sebagai Undang-undang Dasar 1945." (Jimly Asshiddiqie, Konstitusi dan Konstitusionalisme Indonesia, Jakarta, Mahkamah Konstitusi bekerja sama dengan Pusat Studi Hukum Tata Negara Fakultas Hukum Universitas Indonesia, 2003), hlm. 47.

${ }^{9}$ Moh. Mahfud MD, Perdebatan Hukum Tata Negara Pascaamandemen Konstitusi (Jakarta, LP3ES, 2007), hlm. XIV-XV.

${ }^{10}$ Jimly Assiddiqie, Format Kelembagaan Negara, Op. cit., hlm. 58.

${ }^{11}$ Moh. Mahfud MD, Konstitusi dan Hukum Dalam Kontroversi Isu (Jakarta, Rajawali Pers, 2012), hlm. 139.
} 
Kekuasaan judisial didistribusikan kepada Mahkamah Agung (MA) dan Mahkamah Konstitusi (MK). Dalam rangka saling mengawasi dan mengimbangi, organ negara baru juga dibentuk yakni Komisi Yudisial. Komisi Yudisial berfungsi sebagai lembaga pengawas terhadap perilaku hakim-hakim. Pembentukan Komisi Yudisial berkaitan dengan maksud untuk membangun mekanisme checks and balances dalam lingkungan kekuasaan yudisial.

Upaya untuk membangun mekanisme check and balances dalam struktur ketatanegaraan dan sistem pemerintahan Indonesia yang demokratis diterapkan dalam ruang lingkup yang sangat luas. Mekanisme checks and balances diterapkan dalam konteks relasi segenap organ negara baik organ negara utama maupun organ-organ negara penunjang (auxiliary state organ). Pembentukan organ negara penunjang adalah trend baru dalam kehidupan bernegara dan praktik penyelenggaraan negara di Indonesia pascaamademen UUD 1945. Organ-organ negara penunjang adalah organ negara yang menjalankan kekuasaannegara yang tidak serta merta termasuk dalam kategori salah satu cabang kekuasaan menurut doktrin klasik Trias Politica Montesquieu.Pembentukan organ-organ negara penunjang berkembang seiring dengan perkembangan tugas pemerintahyang semakin luas dan spesifik sehingga suatu urusan tidak serta merta dapat dikategorikan sebagai tugas dan fungsi organ negara penyelenggara kekuasaan legislatif, eksekutif atau judisial. Tugas organ-organ negara penunjang bersifat khusus meskipun secara teoretis dapat dikategorikan sebagai komplementer terhadap salah satu cabang kekuasaan negara klasik seperti kekuasaan Komisi Yudisial yang bersifat komplementer terhadap kekuasaan yudisial yang diselenggarakan lembaga peradilan.

Dalam garis besar, dari sudut pandang fungsi, keseluruhan organ-organ penyelenggara negara yang dibentuk pascaamandemen UUD 1945 dapat dibagi dalam 2 (dua) kategori. ${ }^{12}$ Pertama, organ-organ penyelenggara negara kategori organ negara utama (main organ). Organ negara utama (main state organ) terdiri atas (1) MPR, (2) DPR. (3) DPD, (4) Presiden, (5) Mahkamah Agung, (6) Mahkamah Konstitusi dan (7) Badan Pemeriksa Keuangan. ${ }^{13}$ Kedua, organ-organ penyelenggara negara kategori organ negara penunjang (auxiliary state organ) yang disebut Jimly Asshiddiqie sebagai organ negara lapis kedua. ${ }^{14}$

Organ negara penunjang memperoleh kewenangandari UUD 1945 atau undang-undang. Organ negara lapis kedua yang memperoleh kewenangannya dari UUD 1945 adalah (1) Komisi Yudisial, (2) Tentara Nasional Indonesia. Organ negara lapis kedua yang memperoleh kewenangannya dari undang-undang adalah (1) Komnas HAM (2) Komisi Penyiaran Indonesia dan lain-lain. Organ negara lapis kedua meliputi Menteri Negara, Tentara Nasional Indonesia, Kepolisian Negara Republik Indonesia, Komisi Yudisial, Komisi Pemilihan Umum dan Bank Sentral. Kedudukan organ negara lapis kedua sejajar dengan organ negara yang dibentuk berdasarkan undang-undang seperti Komnas HAM, KPK, Komisi Penyiaran Indonesia, Komisi Pengawas Persaingan Usaha dan lain-lain.

Selain organ-organ negara yang disebut di atas, ada organ negara penunjang yang sumber kewenangannya berasal dari peraturan perundang-undangan di bawah UUD 1945 dan undang-undang seperti Komisi Ombudsman Nasional dan Komisi Hukum Nasional (sudah dibubarkan). Organ negara penunjang dibentuk berdasarkan Peraturan Presiden atau Keputusan Presiden. Organ negara penunjang yang lain

\footnotetext{
12 Jimly Asshiddiqie, Penguatan Sistem Pemerintahan dan Peradilan (Jakarta, Sinar Grafika, 2015), hlm. 104.

${ }^{13}$ Ibid., hlm. 101.

${ }^{14}$ Ibid.
} 
adalah Komisi Kejaksaaan yang juga dibentuk berdasarkan Peraturan Presiden. Pembentukan Komisi Kejaksaan masih berkaitan dengan upaya membangun mekanisme check and balances di antara organ-organ negara dalam lingkungan kekuasaan eksekutif.

Pembentukan Komisi Kejaksaan sebagai organ pengawas Kejaksaan tidak terlepas dari kondisi penegakan hukum yang berkembang setelah kejatuhan rezim pemerintahan otoriter Orde Baru. Segenap elemen masyarakat menuntut keterbukaan dan kehidupan yang demokratis dalam segenap aspek praktik penyelenggaraan negara. Tuntutan kehadiran lembaga pengawas kejaksaan mengandung makna kinerja kejaksaan masih jauh dari harapan masyarakat. Pembentukan Komisi Kejaksaan merupakan respon terhadap kondisi sosial-politik pada tahun 2004-2005 terutama berkenaan dengan kinerja Kejaksaan Republik Indonesia. Kondisi sosial politik tersebut berkembang jauh sebelum tahun 2004-2005tetapi mendapat perhatian dan respon pada saat pembentukan Undang-Undang Kejaksaan.

Sesuai dengan kondisi sosial politik sebelum dan pada saat pembahasan undang-undang Kejaksaan, publik menghendaki pembentukan sebuah komisi sebagai kebutuhan yang sudah mendesak. Alasannya, sikap pesimisme dan ketidakpercayaan masyarakat terhadap kemampuan pengawas internal Kejaksaan dalam meningkatkan kualitas dan kinerjanya. ${ }^{15}$ Secara umum, kualitas pelayanan di peradilan yang diberikan penegak hukum kepada publik dan pengawasan internal yang lemah yang dilaksanakan oleh lembaga konvensional menjadikan penegakan hukum sebagai salah satu sektor yang dianggap korup di Indonesia. ${ }^{16}$ Salah satu faktor penyebabnya adalah kinerja lembaga pengawas internal kejaksaan yang lemah dan gagal melaksanakan tugasnya. ${ }^{17}$ Pembentukan suatu komisi independen yang berfungsi melakukan pengawasan kinerja Kejaksaan tidak terlepas dari maksud untuk menghadirkan mekanisme check and balance dalam sistem penegakan hukum pada tataran organ negara lapis kedua dalam ruang lingkup kekuasaan pemerintahan.

Dari segi fungsi, Komisi Kejaksaan bersifat komplementer terhadap pelaksanaan fungsi, wewenang dan tugas Kejaksaan Republik Indonesia. Komisi Kejaksaan diharapkan dapat berfungsi sebagai organ penyeimbang Kejaksaan Republik Indonesia dengan melakukan pengawasan kinerja jaksa dan pegawai kejaksaan. Pembentukan Komisi Kejaksaan diharapkan dapat menghadirkan praktik penegakan hukum yang bermanfaat, berkepastian hukum dan berkeadilan serta demokratis dengan berdasarkan pada prinsip keterbukaan. Kondisi penegakan hukum seperti dikemukakan di atas belum dapat dihadirkan lembaga pengawas internal kejaksaan. Selama ini, penegakan hukum yang dilakukan Kejaksaan dirasakan masyarakat masih jauh dari suasana penegakan hukum yang bermanfaat, berkepastian hukum dan berkeadilan dalam susana kehidupan bernegara yang demokratis berdasarkan prinsip keterbukaan. Dalam bingkai kehidupan bernegara yang demokratis, masyarakat menggantungkan harapan yang sangat besar kepada Komisi Kejaksaan untuk peningkatan kualitas penegakan hukum di Indonesia seperti dikemukakan di atas. Namun, amanat Pasal 38 UU Nomor 16 Tahun 2004 dan harapan masyarakat belum dapat dilaksanakan Komisi Kejaksaan.

Dalam paparan di atas, penulis sudah mengemukakan keberadaan Komisi Kejaksaan sebagai organ negara penunjang yang bersifat mandiri (otonom) yang

\footnotetext{
${ }^{15}$ Choky R. Ramadhan, Kedudukan, Tugas dan Kewenangan Komisi Kejaksaan (Media Hukum dan Keadilan teropong, Volume 1 November 2013), hlm. 4.

${ }^{16}$ Nur Syarifah, Meninjau Efektivitas Kewenangan Komisi Kejaksaan (Media Hukum dan Keadilan teropong, Volume 1 November 2013), hlm. 17.

${ }^{17}$ Ibid.
} 
bertugas membantu Presiden meningkatkan kualitas kinerja jaksa dan pegawai Kejaksaan Republik Indonesiaberdasarkan Peraturan Presiden Nomor 18 Tahun 2011. Komisi Kejaksaan adalah mitra Kejaksaan untuk meningkatkan kualitas kinerja jaksa dan pegawai kejaksaan. Tugas dan wewenang Komisi Kejaksaan diatur dalam Perpres Nomor 18 Tahun 2011 sebagai pengganti dan pembaharuan Peraturan Presiden Nomor 18 Tahun 2005. Komisi Kejaksaan melaksanakan tugas dan wewenang sebagai lembaga pengawas eksternal kejaksaan. Kehadiran lembaga pengawas jaksa dan pegawai kejaksaan eksternal diharapkan dapat menegasikan fanatisme korps yang selalu melekat pada lembaga pengawas internal. ${ }^{18}$. Namun, pelaksanaan tugas dan wewenang Komisi Kejaksaan berdasarkan Peraturan Presiden Nomor 18 Tahun 2011 bukan tanpa hambatan dan kendala. Ada berbagai macam hambatan dan kendala yang dialami dan dihadapi Komisi Kejaksaan dalam pelaksanaan tugas dan wewenangnya. Hambatan dan kendala tersebut berkaitan dengan beberapa aspek organ negara Komisi Kejaksaan sebagai lembaga pengawaseksternal Kejaksaan.Kendala dan hambatan pelaksanaan tugas dan wewenang Komisi Kejaksaan dapat dibagi dalam kategori (1) kendala internal dan (2) eksternal. ${ }^{19}$

Kendala atau hambatan pelaksanaan tugas dan wewenang Komisi Kejaksaan yang bersifat internal yang dapat disebut adalah sebagai berikut. Pertama, kendala dasar hukum keberadaan Komisi Kejaksaan yang lemah yakni Peraturan Presiden Nomor 18 Tahun 2011. ${ }^{20}$ Kedua, kendala kemandirian Komisi Kejaksaan sebagai lembaga pengawas Kejaksaan. Secara formal, Pasal 2 ayat 1 (satu) Perpres Nomor 18 Tahun 2011 menyebutkan Komisi Kejaksaan sebagai lembaga non-strukutural yang bersifat mandiri (otonom). Namun, Pasal 2 ayat 2 (dua) Perpres Nomor 18 Tahun 2011 menyebutkan Komisi Kejaksaan berada di bawah dan bertanggung jawab kepada Presiden.

Kedudukan tersebut dianggap membuat Komisi Kejaksaan tidak otonom (mandiri) dalam melaksanakan tugas dan wewenangnya. Kinerja Komisi Kejaksaan akan dipengaruhi sikap dan komitmen Presiden terhadap kemandirian Komisi Kejaksaan dalam konteks penegakan hukum dalam rangka good and clean government. $^{21}$ Ketiga, kendala dari segi wewenang Komisi Kejaksaan. Sebagai lembaga pengawas, wewenang Komisi Kejaksaan adalah sangat minim sehingga tidak efektif untuk melakukan tugas pengawasan. Kewenangan Komisi Kejaksaan terbatas pada memberikan rekomendasi kepada Jaksa Agung. Tindak lanjut rekomendasi tersebut bergantung kepada Jaksa Agung. Keempat, kendala dari segi personalia untuk melakukan pengawasan terhadap jaksa dan pegawai kejaksaan yang berjumlah 24.000 (dua puluh empat ribu) orang dan 600 satuan kerja. ${ }^{22}$

Kelima, kendala dana yang terbatas untuk melakukan kerja sama dan kegiatan lain yang dianggap perlu dalam pelaksanaan tugas dan wewenang. Keenam, kendala yang membatasi pelaksanaan tugas dan wewenang Komisi Kejaksaan karena Pasal 13 Peraturan Presiden Nomor 18 Tahun 2011. Jaksa yang diperiksa Komisi Kejaksaan akan terkendala jika atasan jaksa tersebut tidak memberikan izin untuk memeriksa bawahannya dengan alasan sedang ditugaskan. Masa penugasan yang tidak jelas

\footnotetext{
${ }^{18}$ Nur Syarifah, Op. cit., hlm. 17.

19 Putu Indrawan Ariadi, Kewenangan Komisi Kejaksaan Terhadap Tugasnya Untuk Melakukan Pengawasan Khususnya Kepada Kewenangan Penuntut Umum (Jurnal Magister Hukum Udayana, Volume 4 Nomor 4 Desember 1025) hlm. 645-653.

${ }^{20}$ Bandingkan dengan pendapat Nur Syarifah dalam Op. cit., hlm. 20.

${ }^{21}$ Bandingkan dengan pendapat Choky M. Ramadhan dalam Op. cit., hlm. 6.

22 Soemarno, Struktur Komisi Kejaksaan Republik Indonesia dan Mekanisme Kerja Dalam Meningkatkan Kinerja Kejaksaan Republik Indonesia (Makalah, Tanpa Tahun), hlm. 7.
} 
membuat pemeriksaan yang hendak dilakukan Komisi Kejaksaan tidak dapat dilaksanakan.

Pada sisi lain, ada beberapa hambatan dan kendala eksternal dialami oleh Komisi Kejaksaan dalam pelaksanaan tugas dan wewenangnya. Pertama, kendala dari segi mitra kerja Komisi Kejaksaan yang sangat terbatas jika dibandingkan dengan jumlah personalia yang diawasi. Kedua, kendala yang bersumber dari lingkungan Kejaksaan sebagi objek pengawasan Komisi Kejaksaan. Nasib hasil pemeriksaan dan rekomendasi Komisi Kejaksaan justru ditentukan oleh lembaga yang menjadi objek pengawasan yakni Jaksa Agung. Sebagai konsekuensinya, tindak lanjut rekomendasi yang disampaikan Komisi Kejaksaan kepada Jaksa Agung akan bergantung pada itikad baik Jaksa Agung. ${ }^{23}$

Ketiga, dukungan dan perhatian masyarakat terhadap pelaksanaan tugas dan wewenang Komisi Kejaksaan yang minimal. Keempat, masyarakat kurang mengetahui hasil-hasil pengawasan yang dilakukan Komisi Kejaksaan karena publikasi yang sangat kurang. Bahkan, kampus yang mempunyai fakultas hukum mengetahui keberadaan dan kinerja serta hasil-hasil yang dicapai Komisi Kejaksaan sangat minimal karena publikasi yang kurang. Kondisi yang disebut dalam poin ketiga di atas berakibat pada poin keempat di bawah. Kelima, dukungan dan perhatian masyarakat terhadap pelaksanaan tugas dan wewenang Komisi Kejaksaan adalah minimal.

Dalam paparan yang dikemukakan di atas, penulis sudah mengemukakan kondisi pelaksaan tugas dan wewenang Komisi Kejaksaan berdasarkan Peraturan Presiden Nomor 18 Tahun 2011. Pelaksanaan tugas dan wewenang Komisi Kejaksaan belum menunjukkan hasil yang dapat meningkatkan kualitas kinerja Kejaksaan seperti dikehendaki UU Nomor 16 Tahun 2004. Kasus-kasus kontroversial yang melibatkan oknum jaksa seperti kasus Pinangki Sirna Malasari masih terjadi sampai dengan sekarang. Namun, dari berbagai macam faktor yang mempengaruhi kinerja Komisi Kejaksaan sebagai lembaga pengawas eksternal, penulis menganggap ada 3 (tiga) aspek keberadaan Komisi Kejaksaan yang perlu diperbincangkan. Ketigas aspek tersebut adalah (1) dasar hukum Komisi Kejaksaan, (2) kedudukan Komisi Kejaksaan sebagai lembaga pengawaseksternal di bawah Presiden, (3) tugas dan wewenang Komisi Kejaksaan sebagai lembaga pengawaseksternal dalam konteks mekanisme checks and balances di antara Komisi Kejaksaan dan Kejaksaan. Namun, ketiga aspek Komisi Kejaksaan sebagai lembaga pengawas eksternal kejaksaan tersebut dibicarakan lebih lanjut dalam paparan di bawah.

\section{Kedudukan, Tugas dan Wewenang Komisi Kejaksaan Sebagai Mitra Kejaksaan Dalam Sistem Ketatanegaraan Indonesia Berdasarkan Sebagai Negara Hukum Demokratis Yang Sejahtera}

Dalam bingkai negara hukum Indonesia sebagai negara hukum kesejahteraan demokratis, reposisi kedudukan dan redistribusi kekuasaan Komisi Kejaksaan perlu dilakukan supaya komisi tersebut dapat mengemban misi dan amanat seperti dikehendaki Pasal 38 UU Nomor 16 Tahun 2004. Reposisi kedudukan dan redistribusi kekuasaan Komisi Kejaksaan bertitik tolak dari prinsip check and balance. Bingkai perbincangan reposisi kedudukan dan redistribusi wewenang dan tugas Komisi Kejaksaan adalah negara hukum Pancasila sebagai negara hukum kesejahteraan demokratis. Dalam konteks reposisi kedudukan dan redistribusi kekuasaan Komisi

\footnotetext{
${ }^{23}$ Marwan Effendi, Kejaksaan RI: Posisi dan Fungsinya Dari Perspektif Hukum (Jakarta, Gramedia Pustaka Utama, 2005), hlm. 150.
} 
Kejaksaan, politik hukum aktivitas reposisi kedudukan dan redistribusi kekuasaan tersebut mengacu pada Pasal 38 UU Nomor 16 Tahun 2016 seperti sudah dikemukakan pada bagian lain. Atas dasar prinsip-prinsip yang dikemukakan di atas, reposisi kedudukan dan redistribusi kekuasaan Komisi Kejaksaan sebagai lembaga pengawas eksternal bukan merupakan cita-cita (gagasan) yang tanpa alasan. Sudah barang tentu, reposisi kedudukan dan redistribusi kekuasaan Komisi Kejaksaan harus dapat menjawab dan menanggulangi hambatan dan kendala Komisi Kejaksaan dalam pelaksanaan tugas dan wewenangnya sebagai lembaga pengawas eksternal Kejaksaan.

Pada hakikatnya, hambatan dan kendala utama Komisi Kejaksaan dalam pelaksanaan tugas dan wewenangnya bersumber dari regulasi yang mengatur keberadaan Komisi Kejaksaan yakni Perpres Nomor 18 Tahun 2011. Problematika dasar hukum keberadaan lembaga pengawas eksternal seperti Komisi Kejaksaan dialami juga oleh yang lain. Komisi pengawas eksternal yang lain seperti Komisi Kepolisian Nasional juga mengalami hambatan dan kendala yang sama. Dasar hukum lembaga pengawas eksternal yang lemah karena lebih rendah dari dasar hukum lembaga yang diawasi adalah kendala utama. Dasar hukum Komisi Kejaksaan lebih rendah dari dasar hukum Kejaksaan Republik Indonesia sebagai objek pengawasan Komisi Kejaksaan. Dasar hukum Kejaksaan Republik Indonesia adalah UU Nomor 16 Tahun 2004. Namun, dasar hukum Komisi Kejaksaan adalah Peraturan Presiden Nomor 18 Tahun 2011, yakni UU Nomor 16 Tahun 2004. Dalam hubungan dengan hambatan dan kendala legislasi atau regulasi yang dikemukakan di atas, Agus Budianto dkk. mengemukakan komentar sebagai berikut:

"Peran lembaga pengawas eksternal pada tingkat penyidikan dan penuntutan perlu ditingkatkan dalam penguatan legislasi. Dengan alasan, bahwa sebuah lembaga negara semisal Kompolnas dan Komjak yang hanya didirikan dengan Peraturan Presiden Republik Indonesia Nomor 17 Tahun 2011 tentang Komisi Kepolisian dan Peraturan Presiden Nomor 18 Tahun 2005 (sudah diganti dengan Peraturan Presiden Nomor 18 Tahun 2011 . . pen.) tentang Komisi Kejaksaan. Kedua dasar hukum dalam bentuk Peraturan Presiden ini memang tidak sebanding (apple to apple) dengan lembaga induk yang diawasinya yaitu Kepolisian dengan UU Nomor 2 Tahun 2002 dan Kejaksaan dengan UU Nomor 16 Tahun 2004."24

Dalam konteks reposisi kedudukan dan redistribusi tugas dan wewenang (kekuasaan) Komisi Kejaksaan sebagai lembaga pengawas eksternal Kejaksaan, para penulis mengajukan gagasan sebagai berikut. Menurut pandangan para penulis, dasar hukum keberadaan Komisi Kejaksaan perlu ditingkatkan menjadi undang-undang. Peningkatan dasar hukum tersebut memiliki maksud supaya Komisi Kejaksaan memiliki dasar hukum yang sama dengan Kejaksaan yakni undang-undang. Kedudukan Peraturan Presiden Nomor 18 Tahun 2011 sebagai dasar hukum keberadaan Komisi Kejaksaanadalah lebih rendah daripada undang-undangsebagai dasar hukum Kejaksaan dari segi hierarkhi peraturan perundang-undangan.

Kedudukan dasar hukum Komisi Kejaksaan yang rendah mengandung konsekuensi terhadap nasib dan keberlangsungan hidup Komisi Kejaksaan. Alasannya, nasib dan kelangsungan hidup Komisi Kejaksaan akan bergantung penuh kepada Presiden jika Komisi Kejaksaan diatur dan ditetapkan dengan Peraturan Presiden. Jika keberadaan Komisi Kejaksaan diatur oleh atau dalam undang-undang, kedudukan Komisi Kejaksaan sebagai lembaga pengawas eksternal akan lebih kuat

${ }^{24}$ Bandingkan dengan komentar Agus Budianto dkk. "Penguatan Fungsi Pengawasan Dalam Sistem Penegakan Hukum Sebagai Upaya Menekan Judicial Corruption” (E-Journal UNDIP), hlm. 166. 
dari berbagai macam aspek termasuk aspek pembiayaan aktivitas Komisi Kejaksaan. Secara ideal, Komisi Kejaksaan lebih baik diatur oleh atau dalam undang-undang sehingga sumber pembiayaan aktivitas Komisi Kejaksaan bersumber secara langsung dari APBN. Pada saat sekarang, sumber pembiayaan aktivitas Komisi Kejaksaanbergantung pada anggaran Menkopolhukam.

Selain hambatan dan kendala legislasi atau regulasi, hambatan dan kendala pelaksanaan tugas dan wewenang Komisi Kejaksaan berkenaan dengan kedudukannya sebagai lembaga pengawas eksternal. Dalam Pasal 2(dua) PerpresNomor 18 Tahun 2011, kedudukan Komisi Kejaksaan berada di bawah dan bertanggung jawab kepada Presiden. Kedudukan Komisi Kejaksaan sebagai lembaga pengawas eksternal di bawah Presiden adalah tidak ideal. Dalam kondisi dan keadaan tertentu, Presiden memiliki peluang melakukan intervensi terhadap tugas dan wewenang Komisi Kejaksaan. Kedudukan yang independenadalah prinsip yang harus ditegakkan supaya Komisi Kejaksaan sebagai lembaga pengawas eksternal jaksa dan pegawai kejaksaan tidak dipengaruhi secara semena-mena untuk kepentingan Presiden. ${ }^{25}$ Dalam hubungan dengan kedudukan Komisi Kejaksaan di bawah dan bertanggung jawab kepada Presiden, Choky R. Ramadhan mengemukakan komentar sebagai berikut:

"Kemandirian Komisi Kejaksaan tidak terdapat pada institusional dan administratifnya. Independensi institusional tidak ada dikarenakan dalam Perpres diatur bahwa Komisi Kejaksaan berada di bawah dan bertanggung jawab kepada Presiden. Pengaturan seperti ini jelas mendudukkan Komisi Kejaksaan berada di bawah eksekutif. Hal ini kurang sesuai dengan prinsip bahwa lembaga penunjang (state auxiliary institution) dibentuk untuk mendukung kerja lembaga eksekutif, legislatif maupun yudikatif yang sudah ada sebelumnya secara independen di luar tiga cabang kekuasaan tersebut." 26

Kekhawatiran intervensi kekuasaan eksekutif (Presiden) terhadap tugas dan wewenang Komisi Kejaksaan adalah hal yang bukan tanpa alasan yang masuk akal. Secara teoretis, kedudukan Komisi Kejaksaan di bawah dan bertanggung jawab kepada Presiden membuka peluang bagi Presiden untuk melakukan intervensi terhadap pelaksanaan tugas dan wewenang Komisi Kejaksaan. Menurut UU Nomor 16 Tahun 2004, Kejaksaan Republik Indonesia berada di bawah Presiden. Kinerja Kejaksaan yang buruk dan maksimal adalah tanggung jawab Presiden baik secara moral, politisdan yuridis. Sebagai akibatnya, dalam konteks relasi kekuasaan PresidenKejaksaan-Komisi Kejaksaan, Presiden akan condong dan berpihak kepada kepentingan Kejaksaan sebagai institusi yang berada di bawah bertanggung jawab kepada Presiden.Dengan alasan seperti dikemukakan di atas, secara ideal dan dalam konteks prinsip separation of power serta mekanisme checks and balance, Komisi Kejaksaan harus merupakan lembaga (komisi) pengawas eksternal yang mandiri seperti keberadaan Komisi Yudisial. Kedudukan yang otonom adalah salah satu kunci untuk meningkatkan kualitas kinerja Komisi Kejaksaan dalam melakukan pengawasan terhadap kinerja jaksa dan pegawai kejaksaan. Jika Komisi Kejaksaan berkedudukan di bawah dan bertanggung jawab kepada Presiden, pada prinsipnya, separation of power dan mekanisme check and balancedalam lingkungan kekuasaan eksekutif di antara organ negara penunjang antara Kejaksaan dan Komisi Kejaksaan tidak mungkin tercapai.

25 Jimly Asshiddiqie, Hukum Tata Negara dan Pilar-pilar Demokrasi Serpihan Pemikiran Hukum, Media dan Ham, Edisi Revisi (Jakarta, Konstitusi Pers/Konpres), Oktober 2006), hlm. 98.

${ }^{26}$ Choky R. Ramdhan, Op. cit., hlm. 7. 
Selain masalah dasar hukum dan kedudukan seperti dikemukakan di atas, aspek ketiga yang perlu diubah berkenaan dengan tugas dan wewenang Komisi Kejaksaan. MenurutPasal 3 Perpres Nomor 18 Tahun 2011 "Komisi Kejaksaan mempunyai tugas (a) melakukan pengawasan, pemantauan dan penilaian terhadap kinerja dan perilaku Jaksa dan/atau pegawai Kejaksaan dalam melaksanakan tugas dan wewenangnya yang diatur dalam peraturan perundang-undangan dankode etik, (b) melakukan pengawasan, pemantauan dan penilaian terhadap perilaku Jaksa/pegawai kejaksaan baik di dalam maupun di luar tugas kedinasan dan (c) melakukan pemantauan dan penilaian atas kondisi organisasi, tata kerja, kelengkapan sarana dan prasarana serta sumber daya manusia di lingkungan Kejaksaan." Inti sari tugas Komisi Kejaksaan menurut Pasal 3 Perpres Nomor 18 Tahun 2011 mencakup3 (tiga) wilayah pengawasan yakni (1) kinerja dan perilaku jaksa dan pegawai kejaksaan dalam pelaksaan tugas dan wewenang, (2) perilaku jaksa dan pegawai kejaksaan di dalam dan di luar tugas kedinasan dan (c) kondisi organisasi, tata kerja, kelengkapan sarana dan prasarana serta sumber daya manusia di lingkungan kejaksaan.

Sebagai lembaga pengawas eksternal, tugas yang diemban Komisi Kejaksaanakan berdaya guna dan berhasil guna jika komisi ini memiliki seperangkat wewenang yang bersifat menentukan hasil akhir pelaksanaan tugasnya. Jika Komisi Kejaksaan tidak memiliki wewenang yang bersifat menentukan hasil akhir pelaksanaan tugasnya. pelaksanaan tugas tersebut tidak akan berhasil dilaksanakan sesuai dengan amanat Pasal 38 UU Nomor 16 Tahun 2004. Apakah Komisi Kejaksaan memiliki wewenang yang bersifat menentukan hasil akhir pelaksanaan tugasnya yang diatur dalam Pasal 3 Perpres Nomor 18 Tahun 2011? Sesuai dengan Pasal 4 Perpres Nomor 18 Tahun 2011, Komisi Kejaksaan memiliki seperangkat wewenang dalam konteks pelaksanaan tugasnya.

Akan tetapi, jika keseluruhan wewenang Komisi Kejaksaan yang diatur dalam Pasal 4 Perpres Nomor 18 Tahun 2011 diteliti, Komisi Kejaksaan tidak memiliki wewenang yang menentukan hasil akhir pelaksanaan tugas-tugasnya. Sebagai contoh, wewenang Komisi Kejaksaan untuk melakukan pemeriksaan ulang atau tambahan seperti dimaksud Pasal 5 Perpres Nomor 18 Tahun 2011 tidak memiliki makna yang signifikan yang menentukan hasil akhir pemeriksaan ulang atau tambahan tersebut. Alasannya, menurut Pasal 7 ayat (1) Perpres Nomor 18 Tahun 2011, hasil pemeriksaan ulang atau tambahan yang diatur dalam Pasal 5 Perpres Nomor 18 Tahun 2011 disampaikan dalam bentuk rekomendasi kepada Jaksa Agung.

Rekomendasi adalah bukan tindakan hukum yang bersifat menentukan terhadap hasil pemeriksaan ulang atau tambahan yang dilakukan Komisi Kejaksaan.Sebagai konsekuensinya, rekomendai Komisi Kejaksaan tidak memiliki efek (akibat) hukum terhadap subjek yang direkomendasikan Komisi Kejaksaan. Sudah barang tentu, seperti sudah diperkirakan secara teoretis, dalam praktik, efektivitas rekomendasi Komisi Kejaksaan masih sangat jauh dari harapan. ${ }^{27}$ Bagaimana jika rekomendasi Komisi Kejaksaan tidak ditindaklanjuti Jaksa Agung? Menurut Pasal 7 ayat (2) Perpres Nomor 18 Tahun 2011,jika rekomendasi Komisi Kejaksaan tidak ditindaklanjuti Jaksa Agung, Komisi Kejaksaan melaporkepada Presiden. Ada 2 (dua) kemungkinan yang akan terjadi berkaitan dengan laporan Komisi Kejaksaan kepada Presiden. Pertama, Presiden akan mengkaji dan meneliti laporan tersebut sebelum melakukan tindakan. Dalam hal kemungkinan pertama yang terjadi, waktu yang dibutuhkan akan sangat lama sehingga ada kemungkinan jaksa yang bersangkutan sudah pensiun atau mungkin justru mendapat

${ }^{27}$ Bandingkan dengan komentar Nur Syarifah, Op. cit., hlm. 29-30. 
promosi ke jabatan yang lebih tinggi. Kedua, Presiden tidak melakukan tindak lanjut berkaitan dengan laporan Komisi Kejaksaan tersebut. Jika Presiden tidak melakukan tindak lanjut berkaitan dengan dengan laporan Komisi Kejaksaan, hasil rekomendasi Komisi Kejaksaan akan berakhir tanpa hasil meskipun uang negara sudah terpakai untuk pelaksanaan tugas Komisi Kejaksaan.

Pelaksanaan wewenang Komisi Kejaksaan seperti dikemukakan di atas akan semakin terkendala karena ketentuan Pasal 13 Perpres Nomor 18 Tahun 2011 yang mengatur "Pelaksaan tugas dan kewenangan Komisi Kejaksaan sebagaimana dimaksud dalam Pasal 3 dan pasal 4 tidak boleh mengganggu kelancaran tugas kedinasan Jaksa dan/atau pegawai Kejaksaan atau mempengaruhi kemandirian Jaksa dalam melakukan penuntutan.” Ketentuan Pasal 13 Perpres Nomor 18 Tahun 2011 sangat mengganggu efektivitas kinerja Komisi Kejaksaan dalam pelaksanaan tugas dan wewenangnya. Putu Indrawan Ariadi mengemukakan komentar dalam hubungan dengan ketentuan di atas sebagai berikut:

"Ada beberapa kendala yang dialami oleh Komisi Kejaksaan yaitu antara lain adalah dari faktor internal dari tubuh kejaksaan itu sendiri. Faktor internal itu sendiri adalah pelaksanaan tugas Komisi Kejaksaan terganjal pada tidak boleh dilakukannya intervensi terhadap kelancaran tugas kedinasan jaksa serta dilarang intervensi dalam hal kemandirian jaksa terkait dengan penunututan . . .."28

Dalam pandangan para penulis, ketentuan Pasal 13 Perpres Nomor 18 Tahun 2011 dapat menjadi dalih atau alasan bagi seorang pimpinan untuk tidak merelakan seorang staf atau anak-buahnya diperiksa Komisi Kejaksaan. Modus operandi yang dapat dilakukan atasan yang bersangkutan adalah dengan alasan jaksa/pegawai kejaksaan yang hendak diperiksa Komisi Kejaksaan masih sedang bertugas. Alasan tersebut sudah lebih dari cukup untuk menghambat atau menunda-nunda pemeriksaan jaksa atau pegawai kejaksaan.Dalam konteks argumentasi yang dikemukakan di atas, Putu Putu Indrawan Ariadi mengemukakan komentar sebagai berikut “. . . ada beberapa dugaan yang muncul (maksudnya: untuk tidak merelakan seorang jaksa atau pegawai kejaksaan diperiksa Komisi Kejaksaan ... pen.) yaitu antara lain kejaksaan tidak ingin keburukan dari tubuh lembaganya tercium oleh masyarakat pada umumnya."29 Fanatisme semangat korps (l'esprit de corps) yang sempit dan berlebihan adalah faktor penyebab yang menjadi pemicu seorang pimpinan tidak mengikhlaskan atau merelakan staf atau anak buahnya diperiksa Komisi Kejaksaan seperti dikemukakan di atas. Menurut para penulis, ketentuan Pasal 13 Perpres Nomor 18 Tahun 2011 harus dicabut dan diganti dengan ketentuan yang menunjang peningkatan pelaksanaan tugas dan wewenang Komisi Kejaksaan. Secara ideal, seorang jaksa/pegawai kejaksaan yang diperiksa Komisi Kejaksaan justru harus tidak diberi tugas untuk sementara waktu sampai proses permasalahannya selesai.

\section{KESIMPULAN}

Berdasarkan hal-hal yang dipaparkan di atas, para penulis dapat mengemukakan beberapa simpulan sebagai bertikut. Pertama, dasar hukum, kedudukan, tugas dan wewenang Komisi Kejaksaan yang diatur dalam Peraturan Presiden Nomor 18 Tahun 2011 tidak dapat mendorong peningkatan kualitas kinerja jaksa dan pegawai Kejaksaan seperti dikehendaki amanat Pasal 38 Undang-undang

${ }^{28}$ Putu Indrawan Ariadi, Op. cit., hlm. 645-653.

${ }^{29}$ Ibid. 
Nomor 16 Tahun 2004 tentang Kejaksaan. Kedua, Peraturan Presiden Nomor 18 Tahun 2011 harus diamandemen terutama yang berkaitan dengan dasar hukum, kedudukan, tugas dan wewenang Komisi Kejaksaan dan pasal yang menghambat pelaksanaan tugas dan wewenang Komisi Kejaksaan.

\section{SARAN}

Dalam hubungan dengan kedua simpulan yang dikemukakan di atas, saransaran yang dikemukakan adalah sebagai berikut. Pertama, Perpres Nomor 18 Tahun 2011 harus segera diamandemen terutama pasal-pasal yang berkenaan dengan dasar hukum, kedudukan, tugas dan wewenang Komisi Kejaksaan serta pasal-pasal yang menghambat pelaksanaan tugas dan wewenang Komisi Kejaksaan. Kedua, dasar hukum Komisi Kejaksaan perlu ditingkatkan menjadi undang-undang dan kedudukannya ditimngkatkan menjadi organ negara penunjang otonom (mandiri) disertai wewenang yang bersifat menentukan hasil akhir pelaksanaan tugasnya sebagai lembaga pengawas eksternal.

\section{DAFTAR PUSTAKA}

\section{Buku}

Hendra Nurtjahya. Filsafat Demokrasi. Jakarta: Bumi Aksara, 2006.

Jimly Asshiddiqie, Konstitusi dan Konstitusionalisme Indonesia.Jakarta: Mahkamah Konstitusi bekerja sama dengan Pusat Studi Hukum Tata Negara Fakultas Hukum Universitas Indonesia, 2003.

-------.Format Kelembagaan Negara Dan Pergeseran Kekuasaan Dalam UUD 1945. Yogjakarta: UII-Press,2004.

-------. Penguatan Sistem Pemerintahan dan Peradilan. Jakarta: Sinar Grafika, 2015,

Moh. Mahfud MD, Perdebatan Hukum Tata Negara Pascaamandemen Konstitusi. Jakarta: LP3ES, 2007.

Konstitusi dan Hukum Dalam Kontroversi Isu. Jakarta: Rajawali Pers, 2012.

Marwan Effendi. Kejaksaan RI: Posisi dan Fungsinya Dari Perspektif Hukum. Jakarta: Gramedia Pustaka Utama, 2005.

Padmo Wahyono. Indonesia Ialah Negara Yang Berdasarkan Atas Hukum. Jakarta: Ghalia Indonesia, 1983.

Sibuea, Hotma Pardomuan. Dinamika Negara Hukum. Depok: Rajawali Pers, 2020.

\section{Undang-undang dan Peraturan Perundang-undangan}

Indonesia Undang-undang Dasar Republik Indonesia Tahun 1945

Undang-undang Nomor 16 Tahun 2004 tentang Kejaksaan

Peraturan Presiden Nomor 18 Tahun 2005

Peraturan Presiden Nomor 18 Tahun 2011 


\section{Makalah, Skripsi, Tesis dan Jurnal}

Agus Budianto dkk. Pengaturan Fungsi Pengawasan Dalam Sistem Penegakan Hukum Sebagai Upaya Menekan Judicial Corruption (E-Journal UNDIP. Semarang).

Choky R. Ramadhan, Kedudukan, Tugas dan Kewenangan Komisi Kejaksaan (Media Hukum dan Keadilan teropong, Volume 1 November 2013).

Nur Syarifah, Meninjau Efektivitas Kewenangan Komisi Kejaksaan (Media Hukum dan Keadilan teropong, Volume 1 November 2013).

Putu Indrawan Ariadi, Kewenangan Komisi Kejaksaan Terhadap Tugasnya Untuk Melakukan Pengawasan Khususnya Kepada Kewenangan Penuntut Umum (Jurnal Magister Hukum Udayana, Volume 4 Nomor 4 Desember 2015.

Soemarno, Struktur Komisi Kejaksaan Republik Indonesia dan Mekanisme Kerja Dalam Meningkatkan Kinerja Kejaksaan Republik Indonesia (Makalah, Tanpa Tahun),

Sulis Setyowaty. Efektivitas Rekomendasi Komisi Kejaksaan Republik Indonesia Dalam Penanganan Laporan Pengaduan Masyarakat (Prosiding Seminar Nasional Enchancing Inovations for Sustainable Development: Dissemination of Unpam's Research Result, Tangerang, Tanpa Tahun.) 